\title{
Um momento favorável para estudar Stéphane Mallarmé pelas lentes retradutórias de Antoine Berman ${ }^{1}$
}

\author{
Caroline Pessoa Micaelia*
}

\section{Um caminho inusitado}

Há muitas maneiras de promover um diálogo entre as obras de dois autores. No entanto, quando um é poeta e o outro teórico, o mais comum acaba sendo utilizar a teoria para a leitura dos poemas. Quando se trata de um poeta estrangeiro e de um teórico da tradução, mais comum ainda é que se analise as traduções dos poemas a partir das ferramentas teóricas. Não foi esse, porém, o caminho escolhido para a elaboração do presente trabalho, que procura, ainda assim, estreitar os laços entre Stéphane Mallarmé (1842-1898) e Antoine Berman (1942-1991). De fato, apesar dos diferentes interesses e do século que os separa, Mallarmé e Berman possuem algumas similitudes biográficas curiosas, que por si só já justificariam outros enfoques. Um deles seria o fato de os dois terem morrido cedo demais; não lhes restou tempo suficiente para desenvolver melhor ou aparar as arestas de suas obras. ${ }^{2}$ Outro seria que ambos tiveram diversos trabalhos esparsos publicados em vida, e - talvez por isso mesmo - que uma parte não negligenciável de suas respectivas obras foi publicada postumamente - isso sem mencionar que

\footnotetext{
1 Partes deste trabalho foram divulgadas no V Colóquio 15 de outubro/VIII ENLIJE (2020) e no V Seminário de Literaturas Francófonas da UERJ (SELIFRAN)/I Seminário Internacional de Literaturas Francófonas da UERJ (SEILIFRAN) (2020).

* Universidade de São Paulo.

2 Aos 49 anos, Berman publicara apenas dois livros, A prova do estrangeiro (1981) e A tradução e a letra, ou, O albergue do longínquo (1985). Mallarmé, um pouco mais velho, aos 56, acompanhara a edição de dois livros de poemas, Poesias (1899) e Divagações (1897).
} 
essas obras foram traduzidas em línguas e contextos de recepção bastante variados.

São, por certo, confluências que não se restringem ao biográfico. Elas também dizem algo sobre o modo fragmentário como as presenças desses autores foram se estabelecendo; quer pela intermitência nas publicações, quer pela flutuação no esforço editorial que se propôs a dar sentido a certos inacabamentos, quer pelas diversas cenas de recepção estrangeiras que as acolheram. Os estudos sobre Mallarmé e aqueles sobre Berman, possivelmente priorizando as publicações mais recentes e interesses locais o que em alguma medida não deixa de ser compreensível -, fizeram com que fossem sendo construídas diferentes imagens de Mallarmé e de Berman, variando pela época, pelo espaço geográfico, linguístico e cultural de recepção e pelo trabalho póstumo mais recentemente publicado. Em contrapartida, e evidentemente, os aspectos textuais que levaram a isso diferem. Mallarmé é notoriamente um poeta difícil do ponto de vista formal, o que sempre criou uma sobrecamada de complicações para as leituras de sua obra, ao passo que Berman, embora bem mais claro, apresenta um texto recheado de sutilezas às vezes tão ou mais potentes do que aquilo que transparece de imediato numa primeira leitura. ${ }^{3}$ Mas ainda assim, a maneira descontínua e inconstante como se deu a circulação da obra de cada um foi determinante para as respectivas recepções.

Em verdade, as particularidades estilísticas se acoplam facilmente aos fatores editorial, geográfico, cultural, histórico e linguístico, e acrescidas a eles, resultam em interpretações peculiares, às vezes bastante localizadas, quando não datadas. No caso de nossos autores, o conjunto dos elementos acima elencados produziu, entre tantos outros, um Mallarmé isolado em sua torre de marfim e um Berman linguista, um Mallarmé cifrador de significados e um Berman filósofo, um Mallarmé autobiográfico e um Berman historiador. Nessas condições, é muito bem-vindo o recente acesso ao conjunto das publicações de cada uma dessas obras - Mallarmé já foi, do que se tem notícia, inteiramente publicado e em boas edições; Berman, se

\footnotetext{
${ }^{3}$ Talvez provenha dessa dificuldade a leitura tão informada quanto apressada de Yves Gambier, no trabalho intitulado "La retraduction: Ambiguiités et défis" (Autour de la traduction, 2012).
} 
ainda não foi, talvez não esteja muito longe disso. Mais completo, o material de trabalho disponibilizado aos pesquisadores hoje oferece a possibilidade de se fazer uma leitura melhor informada e, porque não, mais cuidadosa sobre esses autores, e buscar maneiras de entender como lidar com suas contradições, sejam poéticas, teóricas, filosóficas ou tradutórias. Em suma, buscar maneiras de lidar com as muitas temporalidades das respectivas recepções (e seus lugares, línguas, culturas etc.) - suas contribuições, seus equívocos.

De qualquer forma, essa comparação de Mallarmé e Berman por meio das similaridades entre recepções, malgrado seu interesse e sua importância, tampouco foi o caminho escolhido para este artigo. ${ }^{4}$ Em minha perspectiva de estudiosa de Mallarmé, o que chamou atenção foi algo mais específico, que identifiquei como uma aparente sintonia entre a qualidade do pensamento bermaniano na virada de 1980 para 1990 e a qualidade do pensamento que começou a ter lugar entre os estudos mallarmeanos nesse mesmo momento. É nesse ponto de sua trajetória que Berman parece insistir com mais força na importância da retradução, entendendo-a como ancorada numa relação historicista e metacrítica com as obras. É também nesse ponto dos estudos mallarmeanos que se começa a perceber o valor que uma leitura da historicidade pode ter no que diz respeito a nosso entendimento da poética de Mallarmé, percepção que traz consigo a necessidade de rever de maneira metacrítica a própria trajetória do campo de pesquisa que se dedica ao poeta. Nesse sentido, a metacrítica praticada pelos estudos mallarmeanos entre as décadas de 1980 e 1990 apresentaria ressonâncias com uma metacrítica de raízes romântico-alemãs que está no coração da reflexão bermaniana sobre a tradução.

No que concerne a recepção da obra de Mallarmé, que procuro pensar aqui a partir de Berman, o alcance dessa reciprocidade involuntária pode ainda ser pormenorizado. Em 1998, data que marca as celebrações do centenário de morte do autor de Um lance de dados (1897), alguns

\footnotetext{
${ }^{4}$ Devo reconhecer que meu conhecimento da recepção de Berman não é assentado a ponto de ser explorado num artigo.
} 
especialistas ${ }^{5}$ encarregados de fazer um balanço dos primeiros cem anos de crítica mallarmeana sugerem que, para o próximo século, seria essencial reinserir Mallarmé em sua época, em sua vida e na tradição com a qual ele trabalhou, e que os equívocos de sua recepção ao longo do século XX deveriam ser revisados. Quando isso ocorre, o que se está afirmando é que a crítica mallarmeana havia encontrado seu próprio caminho para fora dos dualismos e modernismos que por muito tempo estiveram no horizonte daqueles que se debruçaram sobre a obra do poeta. Um caminho que, além de uma análise historicista da obra, deve implicar uma análise historicista da própria crítica produzida até então, a qual não poderia ser simplesmente descartada nos estudos do século que, à época, despontava. Diante disso, pode-se supor que, ao englobar uma crítica da crítica, a opção por esse caminho da historicidade seja, já, uma maneira historicista de se pensar. Se não por outra coisa, porque a ideia de metacrítica, dentro do contexto europeu, tem justamente origem na Alemanha e, principalmente, numa das fontes estéticas das quais bebe a própria poética mallarmeana - o romantismo.

O paradoxo da proximidade que vejo entre a recepção mallarmeana e os estudos desenvolvidos por Berman é que, se a preocupação com a metacrítica e a historicidade é o que leva Berman à reflexão sobre a tradução, e mais detidamente, a uma reflexão mais consistente sobre a retradução, o debate sobre Mallarmé na Europa ${ }^{6}$, tanto historicamente como considerando esse momento preciso do final do século XX, não poderia estar mais distante de uma preocupação com a res tradutória. ${ }^{7} \mathrm{O}$ fato de que a vida da obra de Mallarmé, como a das obras de tantos outros autores, se estende para fora das fronteiras da língua francesa e do contexto europeu, é para a maior parte dessa crítica apenas um fato. Isso quando não acontece de o Mallarmé

\footnotetext{
${ }^{5}$ São eles Gordon Millan, Bertrand Marchal e Lloyd James Austin (os dois últimos serão tratados aqui). Esse balanço foi detalhado em minha dissertação de Mestrado. Cf. Micaelia, 2019, p. 129.

${ }_{6}$ "Na Europa" aqui não significa que os principais estudiosos sejam europeus (embora muitos o sejam), mas principalmente que os debates, digamos, "internacionais" sobre Mallarmé - isto é, os que reúnem uma quantidade expressiva de pesquisadores vindos de diferentes lugares - aconteceram e acontecem majoritariamente na Europa.

${ }^{7}$ Como comento mais adiante, é de se contar nos dedos os estudos que partem da abordagem tradutória.
} 
traduzido sequer ser visto como Mallarmé8. Talvez pelos Estudos da Tradução enquanto campo ainda serem relativamente novos ao fim do século passado, talvez pelo texto traduzido ainda ser valorizado pelos estudos literários de maneira tão entusiasta quanto vaga, talvez também por uma compreensão, ainda presente, de que a língua francesa é intrínseca à poética de Mallarmé. Acontece que Mallarmé segue tão vivo em outros lugares e línguas quanto em seus lugar e língua de origem, por mais que suas variadas existências estrangeiras se façam em geral ausentes dos grandes debates e reuniões científicas sobre sua obra.

Assim sendo, a guinada metacrítica e historicista dos estudos mallarmeanos na Europa não é relevante apenas como possibilidade de renovação do olhar para os escritos do poeta; ela é igualmente significativa pois, de maneira indireta e insuspeita, implica num questionamento sobre a ausência da abordagem tradutória, bem como na necessidade de inserir tal abordagem no centro da pesquisa sobre Mallarmé. Explica-se, com isso, meu interesse na pesquisa de Berman sobre a retradução, sobretudo aquela desenvolvida em "La retraduction comme espace de la traduction" (Palimpsestes, 1990). Nesse trabalho, a retradução - e, como mostro no desenrolar de meu estudo, auxiliada pela análise de Simone Petry (2015), para Berman toda tradução é uma retradução - consiste numa forma de perpetuar e dar vitalidade às obras, o que, por sua vez, consiste num desejo maior dos estudos mallarmeanos para o século XXI. É por meio desse paralelo que a reflexão bermaniana contribui para um melhor entendimento do que está em jogo na mudança de paradigma pela qual passam os estudos mallarmeanos ao fim dos anos 1990. Mas para além disso, essa reflexão contribui para a investigação do motivo pelo qual a abordagem tradutória se faz ausente dos debates europeus sobre o poeta, do modo como tal abordagem poderia se pronunciar nesse cenário hoje e do quanto os estudos mallarmeanos têm a ganhar se for garantido um espaço para essa abordagem.

Um modo de observá-lo é a partir do contexto de recepção e tradução de Mallarmé no Brasil. Porque na hora em que enfim nos afinamos aos

${ }^{8}$ Refiro-me ao caso do texto "The Impressionists and Édouard Manet" (1876), de que também trato aqui. 
debates em curso na vertente europeia dos estudos mallarmeanos, o tom parece ser dado antes pela via da tradução do que pela via dos estudos literários. Para explicá-lo melhor, começo explorando alguns elementos e entrecruzamentos das recepções brasileira e europeia de Mallarmé no século XX. Em seguida, desenvolvo um pensamento sobre o olhar historicista por meio de uma aproximação entre a ideia de momento favorável, trabalhada por Berman no ensaio de 1990, e a ideia de ação restrita, proposta por Mallarmé no texto homônimo da recolha Divagações (1897). Volto para os estudos mallarmeanos, com o intuito de detalhar os pressupostos que se colocavam entre as décadas de 1980 e 1990, e aprofundando, ao mesmo tempo, algumas das ideias de "La retraduction comme espace de la traduction", incluindo o modo como elas iluminam esse recorte dos estudos mallarmeanos. Subsidiada pelo Berman de "Critique, commentaire e traduction" (1986), problematizo as compreensões da crítica francesa, sobretudo mallarmeana, a respeito da tradução, assim como a falta de efetivo interesse nesta. E encaminho-me, por fim, para uma reflexão mais prática a respeito de como a retradução, às vezes mais do que a crítica, pode ser uma ponta de lança nos estudos literários, ainda me concentrando em Mallarmé, mas partindo então da circunstância brasileira. Aos motivos teórico-críticos desse percurso, supracitados, vem se juntar uma tentativa, latente, de ler a obra em prosa de Mallarmé pelo viés dos estudos da tradução sem para tanto recorrer à minúcia dos textos traduzidos. Passemos agora a Mallarmé no século XX.

\section{Reflexos de Mallarmé}

Para um leitor talvez menos familiarizado com a recepção europeia de Mallarmé, podem ser úteis, num primeiro momento, algumas considerações a respeito das aproximações e dos distanciamentos dessa recepção com sua vertente brasileira, com as retraduções que produzimos em nosso país - e com o próprio texto do poeta.

A primeira delas diz respeito aos nossos movimentos de recepção (de todas as naturezas, embora aqui eu procure me concentrar nos retradutórios), os quais costumam ecoar a recepção europeia, especializada ou não. Quero dizer com isso que se, quanto às retraduções brasileiras, podemos falar num "primeiro Mallarmé", simbolista, do início do século XX, 
como sistematiza Álvaro Faleiros (2012b) - e aqui lembraríamos dos primeiros tradutores, Escragnolle Dória, Batista Cepelos e Alphonsus de Guimaraens -, é porque a recepção francesa de Mallarmé, até a data de sua morte, considerou-o como o chefe da escola. Da mesma forma, se é possível identificar, por aqui, da década de 1930 até praticamente a de 2000, um "segundo Mallarmé", moderno num sentido vasto (mesmo se por vezes ainda com resquícios simbolistas) - indo de Guilherme de Almeida, passando por Haroldo de Campos e chegando em Dante Milano e Júlio Castañon Guimarães -, é na medida em que, entre os anos 1900 e 1940, Paul Valéry e Henri Mondor trabalharam na criação de uma imagem de poeta de torre de marfim, hermético, que separava arte e vida; e é também e talvez sobretudo na medida em que na década de 1950, em outra direção, estudiosos como Gardner Davies e Robert Greer Cohn transformaram Mallarmé num poeta filosófico, cifrador de significados, em constante crise metafísica.

Contudo, é preciso dizer que esses ecos não são especificidade brasileira. Como veremos a seguir, as leituras produzidas por Valéry, Mondor, Davies e Cohn embasaram, na Europa mesmo, outros tantos estudiosos. E somando a isso o fato de que, ao longo dos cem anos que sucederam a morte de Mallarmé em 1898, sua obra e documentação foram publicadas de maneira esparsa, incompleta e fragmentária9 , o que se tem é

\footnotetext{
${ }^{9}$ Fazendo uma rápida retrospectiva meramente ilustrativa (e não extensiva), Mallarmé publicou em vida poemas e artigos esparsos, A última moda (1974), traduções da obra poética de Edgar Allan Poe (1875; 1888), A tarde de um fauno (1976), Pages (1891), Verso e prosa (1893), as conferências A Música e as Letras (1895) e Villiers de l'Isle-Adam (1897), Divagações (1897) e uma versão provisória de Um lance de dados (1897), incluindo dois materiais didáticos, As palavras inglesas (1878) e Os deuses antigos (1880). Até os anos 1950, pouca atenção foi dada a esses seis últimos trabalhos. As Poesias têm uma republicação em 1899 (preparada por Mallarmé) e outra em 1913 (incluindo alguns poemas comemorativos que Mallarmé havia rejeitado para o volume de 1899); Igitur saiu em 1925 (embora seja datado de 1871) e "Notas sobre a linguagem" em 1926, depois com um complemento em 1929 (o texto data de 1896-1870). Em 1941 temos a primeira biografia do poeta, com pedaços da correspondência, e em 1945, a primeira edição das obras completas, pela coleção Bibliothèque de la Pléiade. Nesse primeiro momento, privilegia-se as Poesias e o Fauno. A partir dele, os estudiosos passam a se debruçar sobre os poemas comemorativos, Igitur, o Lance de Dados e o primeiro volume da primeira coleção da correspondência (ainda para ser lançado). Entre os anos 1950 e os 1980 são publicadas As notas do Livro (1957), As núpcias de Herodiade (1959), Para um túmulo de Anatole (1961), os 11 volumes da correspondência organizada, começando em 1959 e terminando em 1985, e uma série de documentos inéditos é publicada entre 1968 e 1973 (Documentos Stéphane Mallarmé). Das décadas de 1960 a 1980, a crítica (sobretudo a não especializada) procura dar conta dos trabalhos
} 
uma série de complicações para o estudo de sua poética. Falei de algumas delas na introdução, em linhas mais gerais, e mencionando também a recepção de Berman. Especificamente sobre Mallarmé, uma complicação seria, por exemplo, que em cada momento da recepção, alguns trabalhos e documentos, pelo acúmulo de interpretações ou pela menor elaboração do texto (e, portanto, maior facilidade de apreensão), foram sendo privilegiados em detrimento de outros, dando espaço para incongruências de leitura. Outra seria que cada década viu sendo lançada uma parte específica da obra e da documentação, dando origem a equívocos de compreensão tamanhos que, muitas vezes, aquilo que os autores tinham acabado de propor tinha logo em seguida que ser corrigido, pois uma nova informação acabava de ser divulgada.

Também por essas questões, dos anos 1960 aos anos 1980 (com eventuais prolongamentos para a década e o século seguintes), tanto no Brasil como no exterior, cada pensador (tradutor ou não) passou a enxergar Mallarmé como o maior representante de uma ou outra modernidade (pósestruturalista, concreta, psicocrítica, semiótica e assim por diante), e dessa maneira, Mallarmé passou a ser muitos. Para se ter uma ideia, ao se analisar nossa produção entre essas décadas (e vez por outra até o início do presente século), fica claro um maior distanciamento entre a visão brasileira sobre a obra de Mallarmé (tanto da crítica como da tradução) e essa mesma obra. Nossos tradutores e poetas parecem estar em dia com a leitura dos concretos, nossos críticos parecem ler atentamente os filósofos e linguistas francófonos então em voga (Julia Kristeva, Jacques Derrida, Roland Barthes, Michel Foucault e Gilles Deleuze são alguns nomes) e a leitura do próprio texto de Mallarmé, por todos eles, dá a impressão de passar ao largo dessas outras fontes.

Novamente, não se trata de uma tendência brasileira. Mas pode ser que, no Brasil (e quem sabe se em outras geografias de recepção, com suas respectivas línguas), a imagem de Mallarmé tenha sofrido um maior grau de

inacabados: "Notas sobre a linguagem", Igitur, Notas do Livro, Núpcias de Herodiade, Para um túmulo de Anatole. 
refração: o Mallarmé de Manuel Bandeira e de Roberto Alvim¹0 já carregaria nuanças do Mallarmé de Mondor e de Valéry, enquanto o Mallarmé dos concretos (como o dos filósofos e linguistas dos anos 1970 e 1980) já seria um reflexo do Mallarmé de Cohn. Sobre estes últimos, ainda que o tratamento dado ao poeta francês seja em grande medida nutrido pela leitura de um artigo de Mário Faustino (1957) ${ }^{11}$, conforme Faleiros comenta em mais de uma ocasião (2012a, 2012b, 2017), pode-se supor que ele também derive fortemente do contato que Haroldo, em seu período de estudos na França (fim da década de $1960^{12}$ ), teve com os textos de Cohn - nesse período, a parte mais estudada da obra de Mallarmé era precisamente o Lance de dados. Do mesmo modo, não é exatamente uma surpresa hoje para os estudos mallarmeanos que as análises empreendidas por uma Kristeva ou um Derrida, para citar apenas dois exemplos, além de serem demasiado enviesadas e apresentarem problemas importantes, são também bastante impregnadas dos estudos de Cohn ${ }^{13}$. Para fazer a volta: o próprio Faustino, em seu já citado artigo, indica explicitamente a leitura do especialista americano para uma melhor compreensão daquilo que estaria em jogo no Lance de dados (2004 [1957], p. 178).

\footnotetext{
${ }^{10}$ Refiro-me aqui aos textos comemorativos escritos na ocasião em que Mallarmé completaria cem anos, em 1942. São eles: “O centenário de Stéphane Mallarmé", por Bandeira em Seleta de prosa (1977), e “Mallarmé", por Roberto Alvim em Anteu e a crítica (1948). No mesmo ano de centenário, também Otto Maria Carpeaux escreve um texto comemorativo, intitulado "Situação de Mallarmé" (18 de março de 1842), e também esse texto possui ecos das leituras de Valéry e Mondor. Carpeaux, porém, a meu ver, parece colocar-se a uma distância maior de seus antecessores franceses, demonstrando, avant la lettre, preocupações com a exegese e com alguns temas que, na crítica europeia, só viriam a aparecer em Davies. É uma exceção interessante, que valeria a pena investigar em outra oportunidade.

11 "Poesia não é brincadeira" (1957).

${ }^{12}$ Em seu artigo "Mallarmé no Brasil", Sandra Stroparo menciona (2013, p. 198) os estudos de Haroldo em Paris, e seu contato com L'auvre de Mallarmé: Un coup de dés (Robert Greer Cohn, 1951) e Vers une explication rationnelle du "Coup de dés" (Gardner Davies, 1953). Mas o que realmente parece indicar a extensão da leitura de Cohn nas análises e traduções de Haroldo são suas notas para a tradução do Lance de dados (no volume Mallarmé, 1974), cujo esquema é particularmente semelhante ao tipo de notas encontradas no livro de Cohn. Cf. CAMPOS, H. de in MALLARMÉ, 2013 [1974], p. 121 et al. Em todo caso, cumpre apontar, além das duas possibilidades citadas no corpo do parágrafo, o contato dos irmãos Campos e de Décio Pignatari com o livro Joyce et Mallarmé : stylistique de la suggestion (1956), de David Hayman.

${ }_{13}$ Lloyd James Austin ("How ambiguous is Mallarmé?", 1980; "Presence and poetry of Stéphane Mallarmé: International Reputation and Intelectual Impact", 1987), Bertrand Marchal (La religion de Mallarmé, 1988; Mallarmé ou l'obscurité lumineuse (org.), 1997) e Gordon Millan ("Cent ans de critique mallarméenne", 1997) estão entre os especialistas que comentam mais detalhadamente essa questão. Concentro-me nos dois primeiros pois foram os que analisei em outra ocasião (MICAELIA, 2019). Não obstante, outros autores também se ocupam desse assunto.
} 
Falar de Haroldo aqui é relevante. Partindo do princípio de que a tentativa dos estudos mallarmeanos nesse início de século XXI é a de compreender a complexidade própria ao nosso objeto - a poética de Mallarmé -, parece coerente ter em conta uma interpretação - a dos poetas concretos - que foi determinante para a presença dessa poética no Brasil. Reconhecer, em outros termos, seu papel inovador e seu alcance; quer pela divulgação de Mallarmé em português, quer pelo tipo de pensamento sobre tradução então preconizado - uma tradução ávida por soluções criativas como modo de lidar com a dificuldade dos autores escolhidos. E reconhecer, com a mesma energia, que, para a recepção nacional do autor da “Herodiade" (1871) entre os anos 1950 e os anos 2000, essa inovação ${ }^{14}$ significou um afastamento de grandes proporções entre os textos escritos por Mallarmé e a recepção de sua obra aqui no Brasil. Entre outras coisas, pela associação programática da poética mallarmeana ao projeto concreto e pela recorrente falta de clareza nas relações entre as soluções tradutórias criativas e essa poética, admitida sob a argumentação de serem "erros criativos" (CAMPOS, 1975, p. 97) ${ }^{15}$. Isso tudo apesar de já ser possível constatar, na Europa da década de 1980, a insinuação de uma outra proposta para ler o texto mallarmeano.

A despeito da influência que à época os concretos exercem sobre a recepção de Mallarmé no Brasil, esse afastamento parece se abrandar um pouco em 1980, quando uma novidade - ainda não totalmente sem vínculos com o movimento dos irmãos Campos, cumpre dizer - é acrescida ao espaço da retradução de Mallarmé. Uma novidade não negligenciável. Porque cerca de 80 anos depois do lançamento de Divagações (1897) na França, é traduzido o primeiro exemplar da prosa mallarmeana em português brasileiro - “O demônio da analogia" (Revista Código, n. 4), por Inês Oseki-Depré. E o intrigante é que tal dado, em si mesmo suficiente para uma transformação em nossas interpretações, ganha outra dimensão ante a crescente atenção dos

\footnotetext{
14 Certamente não sozinha. A ela poderiam ser acrescentados os ganhos da crítica brasileira - para bem ou para mal - com a leitura das teorias dos já mencionados filósofos e linguistas francófonos dos anos 1970 e 1980.

15 "misunderstandings, perhaps creative, but misunderstandings none the less." A propósito, no tocante a Mallarmé, Austin chama isso de contresens créateurs (1987, p. 47), ou seja, "equívocos, talvez criativos, mas equívocos mesmo assim" (1987, p. 45).
} 
estudiosos europeus, a partir dos anos 1980, pela prosa poético-crítica de Mallarmé. Seja por coincidência ou casualidade - talvez pelo famoso acaso, que um lance de dados jamais aboliria -, essa correspondência entre o que se estava fazendo na Europa e o que se começou a fazer no Brasil parece se apresentar como um estimulante ponto fora da curva em nossa recepção da obra do poeta. Principalmente em se considerando que um interesse mais sistemático de nossa parte pela prosa mallarmeana começa a se manifestar não no âmbito da crítica sobre esse escopo, mas sim no de sua tradução.

Por conta dessas retraduções que começam a surgir, nosso horizonte, entre os anos 1980 e 1990, vai se ampliando, dando vazão a uma outra leitura de Mallarmé. Prenúncio dessa mudança, tais retraduções aparecem como uma oportunidade de a prosa mallarmeana adquirir maior permeabilidade em nosso contexto e nele, por um período, estabilizar-se de determinada maneira. A energia é semelhante àquela que estava no ar em nosso país na segunda metade do século $X X$, quando os poetas concretos começaram a retraduzir Mallarmé - algo de inédito parecia surgir nas normas de nossa cultura tradutória. Esse momento propício, que Berman, em "La retraduction comme espace de la traduction", chama de kairós, é um momento que suspende por algum tempo a necessidade de retraduções; forma e consolida uma leitura; marca um momento preciso na história de uma recepção. É que conforme a presença de um autor vai se estabelecendo numa cultura, leituras vão forçosamente sendo produzidas dentro das restrições de cada época, independentemente de coincidirem com um momento favorável. E enxergá-las em sua necessidade à respectiva época, ou melhor, em sua historicidade face à historicidade da obra a que se referem, parece ser uma boa maneira de conseguir dimensionar o impacto de algo particular ou inédito. Nas próximas páginas, uma aproximação entre o momento favorável de Berman e a ação restrita de Mallarmé explica melhor o interesse de pensar uma obra e sua recepção de um ponto de vista historicista.

\section{O momento favorável, a ação restrita}

De acordo com Berman, kairós, o "momento favorável", é uma categoria temporal que "remete à própria História. Em um dado momento, torna-se 
'enfim' possível traduzir uma obra. Após muitas introduções ${ }^{16}$ eruditas, escolares, muitas adaptações, torna-se possível inscrever a significância de uma obra em nosso espaço linguageiro"17 (1990, p. 4). O autor continua, mais adiante: “Esse tempo (re)surge quando, para uma cultura, a tradução de uma obra torna-se vital para seu ser e sua história. Aí também, naturalmente, só poderia se tratar de uma retradução. Pois é preciso que a obra tenha longamente amadurecido sua presença em nós, para que a necessidade de sua retradução apareça"18 (1990, p. 5). Nessas duas citações, retiradas ambas do final do artigo, tem-se a impressão de certo idealismo ${ }^{19}$; coloca-se a questão do que seria esse momento favorável para a retradução ${ }^{20}$. Para os leitores de Mallarmé, no entanto, tal impressão não deixa de trazer à mente "A ação restrita", poema-crítico que integra a sessão intitulada "Quanto ao livro", de Divagações.

Nesse texto, o poeta desenvolve todo um discurso quanto à ideia de ação em literatura e de que maneira essa ação, a ação operada pela literatura poderia ter um impacto verdadeiramente significativo no meio social. $\mathrm{O}$ título, talvez transpareça, é uma provocação a uma noção que alvorecia entre os movimentos anarquistas do fim do XIX, a ação direta, que nada mais é do que uma ação política, realizada por um indivíduo ou um grupo, sem o recurso a um intermediário (uma organização, um representante etc.).

\footnotetext{
${ }^{16}$ Interessante notar que, por meio desse termo - o qual pode sem dúvida passar despercebido -, Berman retoma as discussões que havia feito tanto em "Tradition - translation - traduction" como em "Da translação à tradução". Mais adiante em "La retraduction comme espace de la traduction", o autor esclarece (1990, p. 4, grifo do autor): "para usar a expressão de Meschonnic, a introdução de uma obra (sua translação). Não sua tradução, no sentido radical do termo." ["pour reprendre l'expression de Meschonnic, l'introduction d'une ouvre (sa translation). Non sa traduction au sens radical du terme."] O "radical do termo" aqui, no caso, é a palavra latina ductio (de ducere, "conduire" em francês), conforme a argumentação dos dois textos de 1988. À exceção das citações de "Da translação à tradução" e A tradução e a letra, todas as traduções de citação são de minha autoria.

17 “Catégorie temporelle, le kairos renvoie à l'Histoire elle-même. À un moment donné, il devient 'enfin' possible de traduire une œuvre. Après maintes introductions érudites, scolaires, maintes adaptations, il devient possible d'inscrire la signifiance d'une œuvre dans notre espace langagier."

18 "Ce temps (re)vient lorsque, pour une culture, la traduction d'une œuvre devient vitale pour son être et son histoire. Naturellement, ce ne saurait être, là encore, qu'une retraduction. Car il faut que, de son côté, l'œuvre ait longuement mûri sa présence en nous, pour que la nécessité de sa retraduction apparaisse."

19 "Ce temps (re)vient lorsque, pour une culture, la traduction d'une œuvre devient vitale pour son être et son histoire. Naturellement, ce ne saurait être, là encore, qu'une retraduction. Car il faut que, de son côté, l'œuvre ait longuement mûri sa présence en nous, pour que la nécessité de sa retraduction apparaisse."

${ }^{20}$ Cabe aqui o rápido lembrete de que Berman se refere aí à categoria "grande tradução".
} 
Apresentando ressalvas quanto a seu uso em literatura, Mallarmé sustenta que a ação proveniente dessa arte precisa ser de outra natureza, pois tudo aquilo que os veículos de imprensa e as altas posições lhe oferecem, é contrário a ela ou defeituoso; nas circunstâncias públicas - "exteriores" é o termo utilizado -, o verbo soa vão. Escreve o poeta (2003 [1897], p. 216): “Assim, a Ação, da forma aqui entendida, literária, não transgride o Teatro; limita-se a isso, à representação - imediato desaparecimento do escrito". ${ }^{21}$ Não apenas - e é este o ponto que me interessa -: que

exteriormente, como o grito da amplidão, o viajante percebe a aflição do apito. 'Sem dúvida', ele se convence: 'estamos atravessando um túnel $-a$ época - este, longo o último, rastejando sob a cidade antes da plataforma toda poderosa do virginal palácio central, que coroa.' 22 (MALLARMÉ, 2003 [1897], p. 217, grifo do autor).

Ora, esse virginal palácio central desenhado poeticamente por Mallarmé traz-nos de volta ao momento favorável de Berman. Não porque essas duas imagens sejam propriamente equiparáveis, mas porque ambas esboçam a compreensão de que uma instância de acabamento subsiste precisa subsistir - a todo o inacabamento - chegando às vezes a fazê-lo por um longo período e com bastante brio (é a "grande tradução" - voltarei a ela). Isso é visto com mais clareza, em "A Ação restrita", na resposta de Mallarmé para o jovem escritor que vem confessar-lhe sua necessidade de agir: "Publique". Porque, segundo lhe parece, "não há Presente [...] Fora dos premier-Paris encarregados de divulgar uma fé no cotidiano nada, e inexperientes se o flagelo reduz seu período a um fragmento, importante ou não, de século"23 (MALLARMÉ, 2003 [1897], p. 217). De maneira semelhante, para Berman, a incompletude natural de cada tradução é o que parece exigir a retradução. Retraduzir, para o autor, é uma necessidade - da mesma maneira que publicar ${ }^{24}$, para Mallarmé, também é uma. Trata-se de uma

\footnotetext{
21 "Ainsi l'Action, en le mode convenu, littéraire, ne transgresse pas le Théâtre; s'y limite, à la représentation - immédiat évanouissement de l'écrit."

22 "Extérieurement, comme le cri de l'étendue, le voyageur perçoit la détresse du sifflet. 'Sans doute' il se convainc 'on traverse un tunnel - l'époque - celui, long le dernier, rampant sous la cité avant la gare toute puissante du virginal palais central, qui couronne.'"

23 "il n'y a pas de Présent [...] Hors des premier-Paris chargés de divulguer une foi en le quotidien néant et inexperts si le fléau mesure sa période à un fragment, important ou pas, de siècle."

${ }^{24}$ No caso aqui trata-se, naturalmente, de publicar um texto literário, não uma tradução de texto literário.
} 
forma de fazer com que as obras reconquistem seu "papel de revelação e de comunicação", sobretudo uma vez que essa necessidade está "inscrita na própria estrutura do ato de traduzir" (BERMAN, 1990, p. 1).

Agora, vale a pena se deter rapidamente no imperativo de Mallarmé - publique. Isso porque Berman, quando discute a retradução, parece pressupor um texto traduzido que foi publicado, muito mais do que uma nova tradução de um texto já traduzido e publicado. Em sua perspectiva (1990, p. 3), “basta que um texto de um autor já tenha sido traduzido para que a tradução dos outros textos desse autor entre no espaço da retradução" 25 . Na realidade, o termo retradução possui sentido amplo em sua teoria, remetendo a todas as traduções publicadas (mesmo aquelas de textos inéditos). Segundo Petry (2015, p. 175), essa acepção responde ao fato de que quando lançamos traduções, mesmo as de textos inéditos, não são jamais nossas primeiras versões. Por isso, um espaço da retradução - e, por consequência, um processo de translação ${ }^{26}$-, digamos, mais sólido (após muitas introduções eruditas, escolares, muitas adaptações), propiciaria um momento oportuno, favorável. Favorável por favorizar, segundo compreendo aqui, uma certa estabilização, um período de estabilidade do papel de comunicação e de revelação de uma obra, em meio à total instabilidade - do sentido, da época, a gosto.

Na verdade, trazendo-o para as categorias de Berman, é o momento em que finalmente torna-se possível uma diminuição da entropia do traduzir, para utilizar seu termo, e, subsequentemente, a abertura de uma determinada cultura para um novo modelo, para novas concepções de tradução (PETRY, 2015, p. 177). Na percepção de Berman, esse novo modelo

\footnotetext{
25 "Il suffit qu'un texte d'un auteur ait déjà été traduit pour que la traduction des autres textes de cet auteur entre dans l'espace de la retraduction."

${ }^{26}$ Um esclarecimento breve sobre esse termo: para Berman (1988a, p. 83), uma primeira diferença se coloca com o termo tradução. "Enquanto a translação destaca o movimento de transferência ou de transporte, a tradução sublinha a energia ativa que anima esse transporte, justamente porque ela remete a ductio e ducere. A tradução é uma atividade que possui um agente, ao passo que a translação é um movimento de passagem mais anônimo." ["Alors que la translation met l'accent sur le mouvement de transfert ou de transport, la traduction, elle, souligne plutôt l'énergie active qui préside à ce transport, justement parce qu'elle renvoie à ductio et ducere. La traduction est une activité qui a un agent, alors que la translation est un mouvement de passage plus anonyme."] A isso é preciso acrescentar que translação consiste numa categoria mais ampla, que diz respeito à transmissão dos saberes [transfert des savoirs] (BERMAN, 1988b, p. 90).
} 
é representado por aquilo que se concordou ${ }^{27} \mathrm{em}$ chamar grande tradução, isto é, uma retradução “amadurecida” (2007 [1985], p. 98), mais experiente - daí a relevância de um espaço da retradução, isto é, um espaço em que convivem diversas retraduções. Por algum tempo, a necessidade de traduzir estará reduzida ou suprida. Pois Mallarmé, quanto ao Livro, não diz outra coisa. Encerra assim “A Ação restrita” (2003 [1897], p. 218):

\begin{abstract}
Você, Amigo, que não deve frustrar anos pois que paralelos ao surdo labor geral, o caso é estranho: peço-te, sem julgamento, por falta de considerações repentinas, que trate minha indicação como uma loucura eu não contesto, rara. Entretanto já a tempere essa sabedoria, ou discernimento, se mais vale - do que arriscar sobre um estado, no mínimo incompleto ao redor, certas conclusões de arte extremas que podem incidir, diamantariamente, nesse tempo para sempre, sobre a integridade do Livro - executá-las, mas e por uma triunfal inversão, com a injunção tácita de que nada, palpitando no flanco insciente da hora, nas páginas mostrado, claro, evidente, a considera pronta; ainda que talvez não seja uma outra em que deva iluminar. ${ }^{28}$
\end{abstract}

Novamente aqui, constata-se uma preocupação com a execução, com sua necessidade. Salvo que - e isso é muito característico do senso crítico demonstrado por Mallarmé em sua obra em prosa - atravessada pela consciência de que nada permite afirmar que a integridade imaginada, no caso, a do Livro, do texto literário como realização, é definitiva - ainda que ela eventualmente o seja. É dizer que o virginal palácio central será em algum momento alcançado e, até o próximo momento favorável, outro túnel da época deverá ser atravessado. Nisso parece haver um entendimento da alternância fundamental entre estabilidade e instabilidade na tradução, na escrita literária e, como mostro nas páginas seguintes, na recepção de uma obra seja em seu espaço de produção, seja em seus espaços de tradução. É uma

\footnotetext{
${ }^{27}$ Considero importante lembrar que essa expressão, "grande tradução", não foi cunhada por Berman. No artigo de 1990 (p. 2, grifos do autor, negritos meus), "Essas traduções são aquilo que se concordou em chamar de grandes traduções."

28 “Toi, Ami, qu'il ne faut frustrer d'années à cause que parallèles au sourd labeur général, le cas est étrange: je te demande, sans jugement, par manque de considérants soudains, que tu traites mon indication comme une folie je ne le défends, rare. Cependant la tempère déjà cette sagesse, ou discernement, s'il ne vaut pas mieux - que de risquer sur un état à tout le moins incomplet environnant, certaines conclusions d'art extrêmes qui peuvent éclater, diamantairement, dans ce temps à jamais, en l'intégrité du Livre - les jouer, mais et par un triomphal renversement, avec l'injonction tacite que rien, palpitant en le flanc inscient de l'heure, aux pages montré, clair, évident, ne la trouve prête ; encore que n'en soit peut-être une autre où ce doive illuminer."
} 
alternância fundamental pois para que um saber se construa, é preciso produzir afirmações, independentemente do tempo que estas perdurem. Elas serão contestadas e se desfarão ou se reconfigurarão, depois, em outras afirmações, não necessariamente da mesma natureza que as primeiras. Por isso, conectar uma ação - isto é, algo que se afirma - a seu contexto de produção e à ação que a justifica (inserida, esta, em seu próprio contexto de produção), significa aprender com as realizações, incluindo suas respectivas restrições e, consequentemente, seus alcances. É esse olhar para a história que reivindicam os estudos mallarmeanos dos anos 1980 e 1990 e que traz a necessidade de uma análise metacrítica do campo em termos muito semelhantes aos que Berman utiliza para pensar a retradução. Antes de mergulhar nessa relação, porém, esclareço brevemente o que estava em jogo para os especialistas em Mallarmé durante esse período.

\section{Metacrítica e historicidade como ecos do romantismo alemão}

Mencionei anteriormente os trabalhos realizados, entre o fim do século XIX e meados do XX, por Valéry, Mondor, Davies e Cohn, e como seus leitores muitas vezes acabaram produzindo severas consequências para os estudos mallarmeanos. O que não mencionei é que esses trabalhos foram capitais para a própria formação do que se pode chamar de estudos mallarmeanos, já que os dois primeiros autores cumpriram o papel fundador de criar uma primeira "imagem" de Mallarmé, ao passo que os dois últimos foram no detalhe de seu texto, movidos por uma notável disposição analítica. Esses estudos se tornaram fontes indispensáveis para as gerações seguintes, incluindo a de dois autores que, a meu ver, dão prosseguimento a um trabalho mais especializado com a recepção de Mallarmé: Lloyd James Austin e Bertrand Marchal.

Como todos os que pensaram sobre a obra do poeta a partir dos anos 1960, esses dois últimos autores tiraram sem dúvida proveito do alicerce fornecido pelos quatro primeiros. Mas foram além. À diferença de Valéry, Mondor, Davies e Cohn, seus sucessores convivem com uma documentação mais volumosa (mesmo se ainda com problemas de organização e de estabelecimento), tendo eles próprios, cada um por seu turno, participado da edição desses materiais - Austin com a primeira coleção da correspondência, 
entre as décadas de 1960 e 1980, e Marchal um pouco depois, principalmente com a reedição das Obras Completas (1998 e 2003) e da correspondência (2019). Como Cohn, são professores universitários ${ }^{29}$ com atividade crítica bastante ativa, especialmente no que diz respeito a Mallarmé. E digo isso pois parece ser no encontro das atividades editorial, crítica e docente, que, pela primeira vez, torna-se possível, na recepção do poeta, uma junção entre as figuras do pesquisador que publica documentos e do pesquisador que analisa criticamente a obra.

À vista de um século que ora dissociou completamente Mallarmé de sua vida, ora estruturou toda uma argumentação crítica em torno da vida com vistas a justificar a obra, essa inovação está longe de ser desprezível. Resulta dela, entre outras coisas, um enfoque mais textual para ler Mallarmé; sem uma análise ensimesmada nem o recurso ao fundo teórico de uma corrente específica. Resulta também uma outra postura frente ao percurso dos estudos mallarmeanos tanto quanto à própria obra do poeta, visto que não se trata mais de destruir todas as leituras anteriores ao se propor uma nova, nem de dizer que todas são, cada uma em seu projeto, igualmente pertinentes. Austin (1980, p. 105) coloca retoricamente a seguinte questão: “será que Mallarmé é tão difícil, obscuro ou ambíguo a ponto de justificar interpretações tão amplamente divergentes? Será que não é possível uma leitura mais simples, colocando o poema no contexto do trabalho de Mallarmé como um todo e na tradição com a qual ele trabalhou?" 30 É estabelecida, assim, uma relação crítica com os trabalhos dedicados ao poeta e com a presença de sua obra na história.

Pode-se supor que as perguntas de Austin nessa ocasião - e outros comentários como esse ${ }^{31}$, no mesmo período -, tal como as concepções de Berman sobre a retradução, espelhem uma conjuntura mais geral de retomada dos românticos alemães, sobretudo os primeiros, marcada pela divulgação tardia na França da tese de doutorado de Walter Benjamin,

\footnotetext{
${ }^{29}$ Austin por Cambridge, St. Andrew's e Manchester, Marchal pela Sorbonne. Cohn foi professor emérito da Stanford University.

30 "The question may now fairly be asked: is Mallarmé so difficult, obscure or ambiguous as to justify such widely divergent interpretations? Is a simpler reading not possible, setting the poem in the context of Mallarmé's work as a whole, and in the tradition within which he worked?"

${ }^{31}$ Citados e comentados mais detalhadamente em minha dissertação. Cf. Micaelia, 2019, p. 129.
} 
publicada originariamente em 1919 (PETRY, 2012, p. 369). No que compete a Berman, a ideia de metacrítica, discutida em L'Épreuve de l'étranger (1984) sob o substantivo alemão Bildung, seria uma das primeiras a terem lugar em seu pensamento; "o movimento que sustenta todas as [suas] reflexões [...] e que se apresenta de modo mais marcante na composição de seu conceito de retradução" (PETRY, 2015, p. 166). Em seu estudo de 2012 como no de 2015, Petry chama a atenção para as noções de autoprocesso e de experiência, as quais culminariam, por sua circularidade e alternância, em uma preocupação com a temporalidade das traduções num sentido dialético que comporta, pela "impossibilidade de realização da comunicação total [...], uma possibilidade de se distanciar do assunto, de modo a poder voltar a ele alçando-se acima de sua própria criação para tentar se expressar com maior lucidez" (2015, p. 169).

Quando Berman propõe a ideia de um espaço da retradução, não parece fazer menção a outra coisa que não, segundo explica Petry (2015, p. 172), a uma relação metacrítica. A diferença em relação a seus contemporâneos mallarmeanos consiste, naturalmente, no fato de que, no caso do teórico, essa relação se dá não entre os trabalhos de crítica literária e a própria literatura, e sim entre um texto original, uma "primeira tradução" (ou primeira versão de um trabalho tradutório, como expliquei anteriormente) e as retraduções já existentes (BERMAN, 2007 [1985], p. 97). O processo de retraduzir com vistas a uma grande tradução mostra-se inteiramente dependente dessa consideração sobre o espaço da retradução. Isso porque a grande tradução, da maneira como Petry (2015, p. 173) parece entender a visão bermaniana, não seria a "melhor tradução", mas a "maior", ou seja, uma retradução informada por aquilo que a antecedeu. É, como analisei, a estabilidade em sua forma mais luminosa e duradoura, viabilizada por um momento favorável. A distinção entre "melhor" e "maior" sugere, seguindo a análise da autora, que, no lugar de uma hierarquia entre retraduções ou de uma perspectiva cronológica, aquilo que permeia todas as retraduções, inclusive a grande tradução, é uma certa interdependência; "as traduções anteriores são inerentes à grande tradução" (2015, p. 173). Aliás, em A tradução e a letra, ou O albergue do longínquo (2007) [1985], numa proposição particularmente historicista, Berman entenderia esse movimento de circularidade e 
alternância como motor de uma "secundaridade" (p. 97) da retradução, rompendo com qualquer acepção de hierarquia entre retraduções. $\mathrm{O}$ autor procura perceber os movimentos de uma obra na história e, ao fazê-lo, demonstra uma preocupação com o exercício de um distanciamento, seguido daquele de um retorno.

No que se refere especificamente a esse olhar da historicidade favorecido pela reflexão sobre as ideais do romantismo alemão, o pressuposto de Austin e de Marchal para as leituras que realizam dos textos de Mallarmé parece ser o de que, sendo a estética romântica - incluindo sua vertente alemã - uma daquelas com as quais Mallarmé dialogou e que foi determinante durante um certo período de sua vida - notadamente, sua juventude -, ela consiste numa fonte relevante para a pesquisa a respeito de sua poética. Um exemplo disso apoia-se em uma das considerações a que o autor de A tarde de um fauno (1876) chegaria em sua célebre crise do Nada $(1867)^{32}$ : a de que, na falta de um Absoluto, caberia à poesia moderna ser crítica. É nessas palavras que Marchal (apud MALLARMÉ, 1995, p. 149) resume o raciocínio triádico ao qual o poeta teria chegado no trabalho com "Herodiade": "Se a Vênus de Milo é a figura da Beleza inconsciente da antiguidade, se a Gioconda é a figura da Beleza cristã, Herodiade é aquela da Beleza moderna doravante consciente de si mesma." 33 Segundo o estudioso, deste ponto em diante Mallarmé passaria a se reconhecer plenamente na ideia de Émile Montégut (apud MALLARMÉ, 1995 [1867], p. 348, grifo do poeta) - aliás tradutor -, segundo a qual todo poeta seria "um crítico antes de tudo"34; e realmente, não há dificuldade em comprovar que, após essa crise, toda sua poesia, de modo mais ou menos declarado, será uma poesia crítica.

Pois é também dialogando com a tradição romântica, mas com Goethe, Novalis (1990, p. 3) e outros, que Berman chega a sua concepção de historicidade. Por isso, não deixa de ser valioso pensar que, em "La retraduction comme espace de la traduction", quando o autor está no ponto alto de seu desenvolvimento sobre a noção de retradução, as palavras que

\footnotetext{
32 Trato-a de modo bem sumário aqui. Essa espécie de crise de fé na poesia está detalhadamente documentada na correspondência de 1866 a 1871.

33 "Si la Vénus de Milo est la figure de la Beauté inconscient de l'antiquité, si la Joconde est la figure de la Beauté chrétienne, Hérodiade est celle de la Beauté moderne désormais consciente d'elle-même."

34 "un critique avant tout".
} 
ele usa são justamente: "é preciso todo o caminho da experiência para chegar a uma tradução consciente de si mesma"35 (1990, p. 3, grifos meus) - as mesmas de Marchal. A bem da verdade, um dos momentos marcantes das leituras que Marchal e Austin fazem de Mallarmé, à despeito das discordâncias que se possa ter ${ }^{36}$, consiste em mostrar que, conquanto haja filosofia em seus poemas, a filosofia chega a contragolpe, e não como fundamento dos poemas. O que acontece é que, pela lógica desses autores, Mallarmé teria chegado a essa noção de poesia crítica, como mencionei anteriormente, pelo trabalho com Herodiade, e não pela leitura de filósofos (Hegel ${ }^{37}$ seria um exemplo). Ele teria chegado a isso pela experiência do trabalho com o texto poético, sendo qualquer peso filosófico, desse modo, produzido de maneira reflexiva dentro desse mesmo texto. Em mais uma ressonância instigante, vale a pena lembrar que o primeiro nome do "Soneto em -yx" não é outro senão "Soneto alegórico de si mesmo" (grifos meus).

Vê-se com isso que, pela escolha dos assuntos e textos a serem analisados, pela relação crítica estabelecida com o percurso dos estudos mallarmeanos, pela interpretação mais textual e mais atenta às problemáticas históricas e culturais em jogo na época de Mallarmé, bem como às tradições com a qual este dialogou, uma circularidade e uma alternância, de maneira parecida com aquela por meio da qual Berman lê o romantismo alemão, estão presentes nos trabalhos de Austin, de Marchal e de outros autores da mesma época - como Gordon Millan, Jacques Rancière, Pascal Durand e assim por diante. Mas à exceção de Durand - e, mesmo aí, de maneira bastante lacunar ${ }^{38}$-, nenhum desses estudiosos faz referência à questão da tradução. Na realidade, entre as investigações do debate europeu nesse momento, raras são as que partem de uma abordagem tradutória ${ }^{39}$. Fato curioso. Ainda mais porque, para o Berman de L'épreuve de l'étranger, a relação das ideias alemãs com a tradução é evidente a ponto de esta última

\footnotetext{
35 "Il faut tout le chemin de l'expérience pour parvenir à une traduction consciente d'elle-même."

${ }^{36}$ Principalmente sobre se Mallarmé leu ou não leu Hegel (Cf. MICAELIA, 2019, p. 138).

${ }^{37}$ Para todos os efeitos, é interessante notar que, tal como consta na correspondência, o resumo elaborado Marchal, citado acima, possui, do ponto de vista esquemático, ares hegelianos.

${ }^{38} \mathrm{O}$ trabalho de Durand é uma espécie de commentaire composé de "Os Impressionistas e Édouard Manet" (e de "Crise de verso"), em que ele vai comentando criticamente - às vezes traduzindo, às vezes parafraseado em francês o texto em inglês -, mas não entra na questão da tradução, especificamente. ${ }_{39}$ Até agora, conto 13 artigos entre 1980 e 1999. Apenas para se ter uma ideia: Keith Bosley (1980), Patricia Parker (1985), Jacques Michon (1989), Daniel Bilous (1991), López Jiménez (1992), Charles Chadwick (1993), Mary Ann Caws (1994), Michael Edwards (1995), Hélène Henry (1995), Judd Hubert (1998), David Muss (1998) e Jany Barretti (1999).
} 
se tornar a base da reflexão; Berman "reconhece na tradução um dos agentes mais importantes da Bildung, em decorrência da função mediadora do estrangeiro nesse processo" (PETRY, 2012, p. 370). Certamente a instituição acadêmica dos Estudos da Tradução é um outro elemento no campo de visão do autor. Mas ainda assim, como estudiosa da tradução tanto quanto estudiosa de Mallarmé, não posso me furtar à indagação sobre essa ausência da tradução nos estudos mallarmeanos dessa época - uma ausência ainda mais preocupante posto que persiste até os dias de hoje $\mathrm{e}^{40}$-, principalmente diante da reciprocidade entre o modo de funcionamento do pensamento bermaniano e aquele dos pesquisadores que, ao fim do século passado, se ocuparam do autor de Divagações.

\section{$O$ próprio da intelectualidade francesa no fim do século $X X$}

Concomitante ao resgate de Walter Benjamin, e em consonância com as discussões despertadas por ele, outro debate vinha à tona entre a intelectualidade francesa nos anos 1970: a questão do próprio versus o estrangeiro. Petry sintetiza (2012, p. 369) bastante bem esse contraste, marcado por um discurso sobre os direitos universais e, na mesma proporção, uma marginalização dos estrangeiros que chegam ao país. É também nesse cenário que vai se fundando um novo campo de estudos, o qual, no imaginário francês dos anos 1980 e 1990, ainda se mostra relativamente difuso. Esse campo, sabemos, é o dos Estudos da Tradução, e não parece de todo incongruente dizer que seu processo de institucionalização poderia justificar a ausência da abordagem tradutória no debate que se fazia sobre Mallarmé naquela época. Porque, de certa forma, não é que os estudos literários simplesmente menosprezassem a tradução como questão. Em seu artigo “Critique, commentaire et traduction", Berman dá um ótimo exemplo de como Maurice Blanchot, para ficar apenas em um dos críticos com os quais o autor trabalha nessa ocasião, celebra a tradução.

Eis o comentário de Blanchot citado por Berman (1986, p. 95) e, em seguida, a apreciação do último a esse propósito:

Será que sabemos de toda a nossa dívida para com os tradutores e, mais ainda, para com a tradução? Nós o sabemos mal. E mesmo que tenhamos

\footnotetext{
${ }^{40}$ Entre 2000 e 2020, de meu conhecimento, constam apenas: Daniel Bilous (2000), Richard Sieburth (2000), Rosemary Lloyd (2001) e Pauline Galli (2014).
} 
gratidão pelos homens que entram com valentia nesse enigma que é a tarefa de traduzir, se os saudamos de longe como os mestres escondidos de nossa cultura, ligados a eles e docilmente submissos ao zelo a que se prestam, nossa gratidão permanece silenciosa, um pouco desdenhosa, aliás por humildade, pois não temos como lhes ser gratos. De um ensaio de Walter Benjamin, em que esse ensaísta excelente nos fala da tarefa do tradutor, eu tirarei alguns comentários sobre essa forma de nossa atividade literária, forma original, e se continuar a ser dito, bem ou mal: aqui estão os poetas, ali os romancistas, ou mesmo os críticos, todos responsáveis pelo sentido da literatura. É preciso contar da mesma forma os tradutores, escritores do tipo mais raro, e verdadeiramente incomparáveis. $(1971)^{41}$

\section{Ao que Berman assertivamente comenta, no rodapé da página} seguinte:

É preciso ler essas linhas de Blanchot com atenção, pelo que elas dizem e também pelo que revelam quase que despercebidamente. Sabemos "mal", diz-nos ele, qual é a nossa dívida para com a tradução. Certo. Mas por que essa persistência em permanecer no meio-saber? A tarefa de traduzir, um 'enigma': qual a essência desse enigma? 'Não temos como lhes ser gratos': certo, mas por que? A tradução é uma 'forma de nossa atividade literária', mas 'original': em quê? Os tradutores, 'escritores do tipo mais raro, e verdadeiramente incomparáveis': em que consiste essa 'incomparabilidade'? Por que cada uma dessas afirmações permanece a tal ponto no implícito ou no ainda-não-pensado? O que impede o crítico de se aventurar mais ante a esse 'enigma' do traduzir? O texto todo deixa muitas interrogações. ${ }^{42}$

\footnotetext{
41 “Savons-nous tout ce que nous devons aux traducteurs et, plus encore, à la traduction? Nous le savons mal. Et même si nous avons de la gratitude pour les hommes qui entrent vaillamment dans cette énigme qu'est la tâche de traduire, si nous les saluons de loin comme les maîtres cachés de notre culture, liés à eux et docilement soumis à leur zèle, notre reconnaissance reste silencieuse, un peu dédaigneuse, d'ailleurs par humilité, car nous ne sommes pas en mesure de leur être reconnaissants. D'un essai de Walter Benjamin, où cet essayiste excellent nous parle de la tâche du traducteur, je tirerai quelques remarques sur cette forme de notre activité littéraire, forme originale, et si l'on continue de dire à tort ou à raison: il y a ici les poètes, là les romanciers, voire les critiques, tous responsables du sens de la littérature, il faut compter au même titre les traducteurs, écrivains de la sorte la plus rare, et vraiment incomparables."

42 "Il faut lire ces lignes de Blanchot avec attention, pour ce qu'elles disent et aussi révèlent presque à leur insu. Nous savons 'mal', nous dit-il, ce que nous devons à la traduction. Certes. Mais pourquoi cette persistance à rester dans ce demi-savoir? La tâche de traduire, une 'énigme': quelle est l'essence de cette énigme? 'Nous ne sommes pas en mesure de leur être reconnaissants': certes, mais pourquoi? La traduction est une 'forme de notre activité littéraire', mais 'originale': en quoi? Les traducteurs, 'écrivains de la sorte la plus rare, et vraiment incomparables': en quoi réside leur 'incomparabilité'? Pourquoi chacune de ces affirmation [sic] reste-t-elle à ce point dans l'implicite ou le non-encore-pensé? Qu'est-ce qui retient le critique de s'aventurer plus avant dans l' 'énigme' du traduire? Tout le texte laisse plein d'interrogations."
} 
Vê-se, então, que a tradução é entendida por Blanchot como "uma atividade muito importante, mas muito misteriosa, da qual não convém falar senão em termos muito gerais" (AUSTIN, 1995 [1967], p. 250). Ironicamente, essa definição de Austin, afiada, não se refere à atividade tradutória, mas ao modo como Henri Mondor trata da atividade poética de Mallarmé na biografia que lhe dedica e que é a primeira a ser publicada, Vie de Mallarmé (1941). O interessante disso é que, a despeito da crítica que faz a Mondor, Austin, anos mais tarde, no estudo "Mallarmé critique d'art" de 1974, produz um discurso tão evasivo quanto o de seu colega. Esse discurso, por sua vez, não é sobre a poética mallarmeana, mas sobre o fato de o artigo "The Impressionists and Édouard Manet" (1876) de Mallarmé, cujo original em francês tem paradeiro desconhecido, ser uma tradução. “Os Impressionistas e Édouard Manet" é, com efeito, um exemplo notável das muitas maneiras como a crítica europeia poderia ter dado mais atenção à questão da tradução. Ocorre, na contramão disso, que esse texto, o mais importante texto em prosa que Mallarmé escreveu nos anos 1870, fundamental para a pesquisa sobre o estilo de Divagações, foi visto de soslaio ao longo de praticamente todo o século XX. Questionava-se a qualidade do inglês de Mallarmé (que sequer o havia traduzido), a autoria do tradutor George T. Robinson, a qualidade da tradução face à suposta qualidade do texto francês de Mallarmé. Na verdade, mesmo nos momentos em que se valorizava esse texto, ele era valorizado apesar de ser uma tradução.

Isso está, no mais, muito nítido no posicionamento dos editores das Obras Completas, seja em 1945 ou em 2003: Mondor o considera o estudo mais importante que Mallarmé consagrou à pintura, mas recusa-se a inserilo na primeira edição (1945); Marchal, entendendo-o como um estudo capital, insere-o na edição mais recente (2003), mas nas notas de rodapé a uma retradução para o francês. ${ }^{43} \mathrm{E}$ está nítido, ainda, na desatenção ao fato de que entre 1959 e 2006 foram produzidas seis retraduções desse texto em francês. Em resumo, as palavras que, em 1986, Berman (p. 96) utiliza para definir o comentário de Blanchot, bem como os de outros autores, aplicamse perfeitamente ao caso dos estudos mallarmeanos: nada muda "o fato de que para além dessas declarações de princípio, a crítica parece indiferente à

${ }^{43}$ Para mais informações sobre esse texto e sua trajetória na recepção de Mallarmé, cf. MICAELIA, 2019, p. 150. 
tradução real." 44 Pois por mais valorosas que sejam as atividades críticas de Austin e Marchal, sua importância global para a leitura de Mallarmé, o que fica claro é que elas não pretendem dar abertura para a tradução como questão, e muito menos como abordagem. Esse é, a meu ver, um dos limites da reflexão produzida por esses pesquisadores e o ponto fulcral em que divergem de Berman. Pois a tentativa de Berman é, no sentido oposto, estabelecer um novo espaço para a tradução no contexto contemporâneo da crítica e da teoria da tradução justamente por ir de encontro a abordagens tradicionalistas (PETRY, 2012, p. 374).

Berman, quanto a ele, poderia também ser interpelado na maneira como entende esse novo espaço para a tradução, "não-etnocêntrico", mas marcado, como escreve Sherry Simon (2001, p. 26), "por um significativo coeficiente francês" 45 : "Berman fala, mais do que ele próprio dá a entender, a partir de um contexto especificamente francês". ${ }^{46}$ E não unicamente pela divisão entre um "próprio" e um "estrangeiro" não funcionar para muitos países, como Simon expressa ser o caso do Canadá. Na introdução a L'épreuve de l'étranger, Berman define o que chama de "francês estrangeiro", que englobaria tanto o francês (que aliás não é um só) dos países francófonos como o francês de pessoas que não estão no contexto da francofonia - o exemplo utilizado é Becket. Isso é bastante problemático, pois significa que mesmo aqueles que têm o francês por língua materna são considerados, por não estarem na França continental - ou na França tout court -, estrangeiros à língua francesa. Esse posicionamento é flagrante numa frase como: "tem-se estrangeiros escrevendo em francês e por isso imprimindo o selo de sua estrangeireza [étrangeté] em nossa língua" (1984, p. 18). O francês, pela expressão "nossa língua", seria a língua dos franceses da França. ${ }^{47}$

Ora, isso não equivale a dizer, em absoluto, que os estudos mallarmeanos dos anos 1980 e 1990, do ponto de vista das considerações sobre tradução, estão em pé de igualdade com Berman. Os mallarmeanos ainda parecem ver a tradução como "uma transferência de signos e

\footnotetext{
44 "cela ne change rien au fait qu'au-delà de ces déclarations de principe, la critique semble indifférente à la traduction réélle."

45 "marque d'un très fort coefficient français".

46 "Berman parle, plus qu'il ne le souligne lui-même, à partir d'un contexte spécifiquement français." Petry também comenta isso em seu artigo de 2015. Cf. PETRY, 2015, p. 170.

47 Esse parágrafo é resultado das reuniões do Grupo de Estudos Tradução em Relação (PPG LETRA/USP), coordenado por Álvaro Faleiros. Agradeço aos colegas pelas discussões e credito-lhes parte dessas ideias.
} 
significados, e de realização quase mecânica, e o original, nesse âmbito, é a única obra de arte envolvida no processo" (PETRY, 2012, p. 374), ao passo que Berman está muito longe desse tipo de compreensão. Não obstante, a impressão que se tem é a de que visão da língua francesa da França como “o próprio" é uma característica comum entre a intelectualidade francesa dessa época, por maior que seja o grau de distanciação, o senso crítico ou o esforço de colocar certos tradicionalismos em cheque. ${ }^{48}$ Tampouco trata-se aqui de dizer que os meios invalidam por inteiro os fins. Seria contraditório, haja vista o presente trabalho, não pensar nesses limites de maneira metacrítica. Porque não há dúvidas de que, pesados tais limites, assim como o aparente desinteresse da vertente europeia da crítica mallarmeana pela questão da tradução em especial e a parca relação direta da teoria de Berman com a

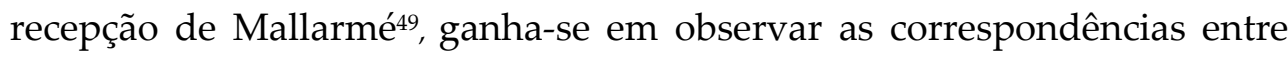
essas instâncias.

Os estudos dessa última escola mallarmeana do século XX - iniciada com Austin e consolidada por Marchal - e o começo de uma ponderação mais substanciosa sobre a questão da retradução têm grande importância. Não visam uma ruptura total, como fizeram as vanguardas do início do século, nem uma desconstrução, como fizeram certos filósofos e linguistas de meados do século. Viu-se aqui, pela análise de alguns aspectos de "A ação restrita", que, trazida para o próprio contexto da obra de Mallarmé, esse tipo de ponderação, conciliadora porém crítica, está no coração do tipo de reflexão que o poeta desenvolve em Divagações ${ }^{50}$, e é possível ver vislumbres disso na ambição, comum entre Berman e seus contemporâneos mallarmeanos, de fazer com que as obras reconquistem seu papel de comunicação e de revelação. É em relação a isso, a meu senso, que as investigações bermanianas sobre o espaço da retradução como um espaço de diálogo histórico e metacrítico, fornecem, da perspectiva dos estudos

\footnotetext{
${ }^{48}$ Berman buscará fazê-lo por meio de seus questionamentos sobre a língua materna, no mesmo L'épreuve de l'étranger (p. 13).

${ }^{49}$ E não com a própria obra de Mallarmé, a qual é, efetivamente, discutida em um item de $A$ tradução e a letra ("Mallarmé e a nova língua-rainha") - livro em que, à propósito, volta e meia vemos citado o nome do poeta.

${ }^{50}$ Para citar um exemplo flagrante, vem à mente "Crise de verso" (MALLARMÉ, 2003 [1897], p. 205): "Testemunha dessa aventura, na qual quiseram em papel mais eficaz, embora não convenha a ninguém, dirigi-lhe, ao menos, meu fervente interesse; e já é hora de tocar no assunto, preferivelmente à distância como se fosse quase anônimo." [“Témoin de cette aventure, où l'on me voulut un rôle plus efficace quoiqu'il ne convient à personne, $j^{\prime} y$ dirigeai, au moins, mon fervent intérêt ; et il se fait temps d'en parler, préférablement à distance ainsi que ce fut presque anonyme."]
} 
literários, instrumentos úteis para se pensar as relações críticas que podemos, atualmente, firmar com as obras literárias, formal e temporalmente ${ }^{51}$. Guardadas as devidas proporções, essa me parece ser uma maneira produtiva e, até certo ponto, pragmática, de compreender o que começou a acontecer com a recepção de Mallarmé nos anos 1980 - e que dá indícios de se estender, embora repaginado, até os dias de hoje ${ }^{52}-$, uma mudança que veio acompanhada da valorização de Divagações, das conferências (A Música e as Letras e Villiers de l'Isle Adam), dos Versos de circunstância, da crítica de arte e da produção jornalística do poeta. Seja no exterior, seja no Brasil.

\section{Um momento favorável se anuncia...}

Na década de 1980, quando as primeiras prosas de Mallarmé começam a ser retraduzidas em nosso país, nada disso está muito nítido. Mesmo assim, é como se, depois de quase um século de translações dos mais diversos tipos, o contexto estivesse finalmente apto para retraduções desse escopo da obra do poeta. A essa altura, Mallarmé já havia tido sua parcela de grandes traduções brasileiras em verso - e quanto a isso, algumas peças das Poesias de Augusto de Campos são exemplares. Mas a tradução da prosa parecia exigir outra coisa, algo que não estava exatamente definido. Sobre isso, o que se pode afirmar é que, na hora em que um momento favorável para essas retraduções começa a se anunciar, constata-se simultaneamente um processo de abertura das normas de tradução em nossa cultura, para falar com Petry (2015, p. 177), e junto a tal abertura, o aparecimento ou a difusão de outras possibilidades críticas. Entra em cena algo da ordem daquilo que, segundo

\footnotetext{
${ }^{51}$ E a elas caberia acrescer a noção de translação, conforme aponta Sherry Simon: "A translação se quer uma teoria geral da passagem de uma obra entre uma 'língua-cultura' e outra, da maneira como ela é revelada, assinalada, integrada num corpus de ensino, e do processo das traduções e retraduções, bem como a sequência de comentários críticos envolvida. [...] A noção de translação é essencial a essa consciência histórica, uma vez que Berman quer mostrar que cada ato de tradução está preso num envelope de níveis interpretativos, num feixe de limitações e liberdades, numa mediação que compreende a um só tempo determinantes conceituais, estéticos e políticos." [“La translation se veut une théorie générale du passage d'une œuvre d'une "langue-culture » à une autre, la manière dont elle est révélée, signalée, intégrée dans un corpus d'enseignement, et le processus des traductions et retraductions, ainsi que la séquence des commentaires critiques qui l'entoure. [...] La notion de translation est essentielle à cette conscience historique, puisque Berman veut montrer que chaque acte de traduction est pris dans une enveloppe de niveaux interprétatifs, dans un faisceau de contraintes et de libertés, une médiation comprenant à la fois des déterminants conceptuels, esthétiques et politiques."]

${ }^{52}$ Evidentemente, essa é uma outra história. Para o presente trabalho, o mais importante é guardar no espírito que essa disposição mais textual na leitura do texto de Mallarmé parece ter vindo para ficar.
} 
a autora (2015, p. 177), Berman compreende como "um discurso de inclusão, e não de exclusão do que está posto".

Maurício Cardozo (2009, p. 104) tem razão ao afirmar que, para Berman como para os poetas concretos, a crítica de tradução estaria dissociada da elaboração de um "inventário dos desacertos" de uma tradução ${ }^{53}$. Contudo, e sem pretender negar as proximidades históricas entre essas duas poéticas do traduzir, é preciso enfatizar que há desacordos importantes entre elas. Um desacordo mais imediato é que a teoria de Berman, embora não possa ser vinculada a uma cronologia (na contramão do que argumenta Yves Gambier, em seu artigo de 2012), tampouco se insere num paradigma sincrônico, como aquele estabelecido pelos concretos; viuse, até aqui, sua preocupação com a historicidade. Mas há um outro desacordo, mais discreto, mesmo se interessante para este trabalho, encontrado na maneira como Berman e Haroldo lidam com o mesmo problema: "a palavra vermelha" na tradução que Hölderlin fez da Antígona (442 a.C) de Sófocles. O caso é que Hölderlin verteu, na frase “Tí $\delta$ ' $\varepsilon \sigma \tau$;

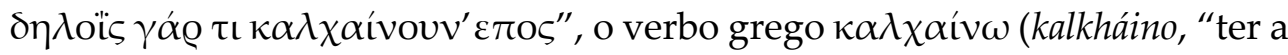
cor escura da púrpura") da seguinte forma: "Du scheinst ein rotes Wort zu färben", que em francês ficou "Tu semble teindre une rouge parole" (BERMAN, 1986, p. 104) e, em português, "Tua fala se turva de vermelho" (CAMPOS, 1974, p. 93).

O posicionamento dos dois tradutores é realmente muito próximo. Para Haroldo (1974, p. 96), a proposta de Hölderlin é notável a despeito de seu limitado conhecimento de grego e, por consequência, de seus frequentes equívocos de leitura e interpretação do texto original. Trata-se de um erro criativo, da mesma qualidade dos que Ezra Pound produziu em suas traduções do chinês; "seu método de verter é a literalidade exponenciada, a literalidade à forma (antes do que ao conteúdo) do original)" (1974, p. 98). Para Berman (1986, p. 105), a comparação entre a escolha de Hölderlin e a do filólogo André Mazon (que traduziu a frase por “Quelque propos te

\footnotetext{
${ }^{53}$ Se priorizo aqui um debate sobre os concretos, não é entretanto sem a consciência de que, em se caminhando por outros lugares, ainda dentro disso que Faleiros chamou de "Mallarmé moderno", é possível observar que entre os anos 1980 e 1990, outros tradutores do Mallarmé versificador, à exemplo de Dante Milano e Castañon Guimarães operam por princípios semelhantes, quando não pela celebração da tradução à maneira concreta (FALEIROS, 2012, p. 24). Do ponto de vista da poesia em verso, Ana Cristina César (1980) e Claudio Veiga (1999) são os tradutores que começam, segundo o crítico, a apontar para um "terceiro Mallarmé”, inscrito na história.
} 
tourmente, c'est clair", isto é, na tradução que faço, "Algo te atormenta, está claro") revela que aquele optou pelo "sentido primeiro" e este pelo "sentido segundo", embora sejam estes "os dois possíveis do traduzir". Berman (1986, p. 105), tal como Haroldo, demonstra predileção pela escolha de Hölderlin, escrevendo que " $\kappa \alpha \lambda \chi \alpha$ ív $\omega$ realmente quer dizer 'atormentar'. Mas esse 'querer-dizer', em que a visão designativa recalca a visão imagética, deixa para trás o verdadeiro 'dizer' do verbo. E é isto que a tradução literal encontra". ${ }^{54}$

No detalhe desses posicionamentos aparentemente tão próximos transparece, entretanto, uma maior propensão à apreciação também de uma tradução "mais semântica" em Berman, que aponta as vantagens do texto filológico, por mais que considere a tradução de Hölderlin melhor realizada. Ao tipo de tradução produzida por André Mazon, Haroldo faz uma crítica de maior dureza. Escreve (1974, p. 98, grifos meus) que a "palavra vermelha [...] aparece, na versão universitária da Antígone das edições 'Les Belles Lettres', como, simplesmente: 'quelque propos te tourmente'." A referência a ela, portanto, se dá pelo adjetivo universitária, empregado num sentido pejorativo que se confirma pelo advérbio utilizado, logo em seguida, para definir a solução: simplesmente. Também parece comprovar minha leitura a maneira como Haroldo se explica, posteriormente nesse mesmo texto, como que buscando se defender de ter se valido da tradução de Mazon para produzir a sua própria: "Para penetrar melhor o texto altamente hermético de Hölderlin, é verdade, cotejei-o com a versão francesa da já citada edição 'Les Belles Lettres' da tragédia de Sófocles. Mas isto, unicamente, para procurar conscientemente seguir o poeta alemão em suas transgressões do texto original" (1974, p. 101, itálico de Haroldo, negritos meus). Ademais, vale notar que Haroldo, em todas as referências à tradução de Mazon, furtase a mencionar o nome do tradutor, aludindo a seu texto como a tradução “da edição 'Les Belles Lettres'”. ${ }^{55}$

Face a esse tipo de posicionamento, certamente mais próximas da crítica de tradução bermaniana ${ }^{56}$, em minha leitura, e mais representativas

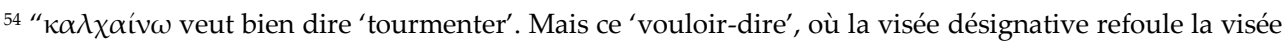
imageante, laisse derrière lui le véritable 'dire' du verbe. Et c'est cela que retrouve la traduction littérale. Ce qui compte pour elle, c'est la vivante oralité du dire épique.".

55 Essa comparação dos textos de Berman e Haroldo sobre a tradução de Hölderlin foi sugerida por Henrique Provinzano Amaral, a quem agradeço.

${ }^{56} \mathrm{O}$ quão próximas, seria uma outra questão.
} 
do momento em que as prosas de Mallarmé começam a ser traduzidas por aqui são as aproximações que Faleiros chama de textuais, representadas, entre outros, por José Paulo Paes, Paulo Vizioli e Mário Laranjeira. Assaz diferentes entre si, essas formas de pensar a tradução podem ser agrupadas na medida em que possuem um vínculo geracional e adotam, segundo Faleiros (2009, p. 255):

\footnotetext{
um outro conjunto de perspectivas teóricas. Essa nova abordagem, que chamamos de "semióticas e textuais [...] propõe um equilíbrio dinâmico entre a forma, o sentido e as características teóricas do texto literário': (FALEIROS, 2005, p. 61). Há, pois, uma certa desconfiança em relação aos excessos de liberdade da corrente antropofágica [...].
}

Laranjeira, principalmente, parece ser uma figura de pertinência para o que venho discutindo neste trabalho. O teórico explora, em Poética da tradução (2003), uma série de problemas tradutórios utilizando-se do texto mallarmeano, além de demonstrar algumas correlações produtivas com Berman, entre as quais poderiam ser destacadas rapidamente uma leitura ativa de Henri Meschonnic e uma preocupação com a significância de um texto. Enquanto Laranjeira (2003 [1993], p. 81, grifos meus) propõe que "na tradução do poema, o que se busca transladar não é o sentido, visto como inerente a uma estrutura linguística, mas a significância", Berman, recordo, entende que o momento favorável é quando torna-se possível inscrever a significância de uma obra em nosso espaço linguageiro.

Seria possível até mesmo se aventurar mais nesse paralelo e dizer que, em Laranjeira, cintila uma preocupação com a historicidade e a metacrítica de um modo talvez análogo àquilo que Berman propõe pela Bildung. É da seguinte forma que o brasileiro (2003 [1993], p. 147, grifos meus) conclui seu livro:

\footnotetext{
Finalmente, acredito ter demonstrado que uma poética da tradução que penetre nas profundezas da geração do poético valendo-se dos instrumentos de análise aqui propostos e que se manifeste numa prática inserida na historicidade do sujeito e do traduzir, de modo a resolver dialeticamente (não a suprimir) as tensões múltiplas que envolvem o ato tradutório, está em condição de superar as ideologias dualistas e de produzir poemas que venham enriquecer a cultura onde passam a conviver com todos os outros nela existentes.
} 
O trecho demonstra com precisão, especialmente para o que concerne as prosas de Mallarmé traduzidas no Brasil, em que consistiria uma das novas possibilidades críticas para as quais nossa cultura foi se abrindo entre as décadas de 1980 e 1990, e que aponta para um diálogo produtivo a um só tempo com as categorias bermanianas e com o modus operandi dos estudos mallarmeanos nesse mesmo período.

Em sua leitura de Mallarmé, porém - e isso como que atesta o que comentei anteriormente sobre a distância entre a crítica brasileira e a obra do poeta -, Laranjeira se afasta de uma interpretação mais textual, entendendo que Mallarmé, em "Crise de verso", “opõe a 'reportagem', que não é poética, à 'poesia'" (2003 [1993], p. 47, grifos meus), quando, na realidade, Mallarmé, no texto em jogo, só faz apontar uma diferenciação corrente em sua época. ${ }^{57}$ Distinção notável entre uma compreensão de Mallarmé como cifrador de significados e uma de Mallarmé como testemunha crítica de seu próprio tempo. Distinção que diz, em síntese, muita coisa no que compete a esse último Mallarmé do século XX e como ele chegou até nós - ou melhor, ao modo como contribuímos ativamente para sua construção, apesar de praticamente ausentes do debate europeu. Porque conquanto "O demônio da analogia" de Oseki Depré e os Poemas (1990) ${ }^{58}$ de José Lino Grünewald possuam ainda muitas ressonâncias com o movimento concreto, "Queixa de outono" (1989) ${ }^{59}$ de Fúlvia Moretto, “O Livro, instrumento espiritual" e "O mistério nas letras" (1991) ${ }^{60}$ de Amálio Pinheiro, e as Prosas de Mallarmé $(1995)^{61}$ de Dorothée de Bruchard, muito pouco têm a ver com a estética concreta - sinalizam, já, uma outra coisa.

Observando simultaneamente a crítica de literatura que Laranjeira esboça por sua leitura de "Crise de verso" e essa mudança de tom nas retraduções brasileiras da prosa mallarmeana, seria possível depreender que chegamos ao último Mallarmé do século XX, um Mallarmé da prosa, pela via da retradução. E isso é não deixa de ser expressivo. Significa que talvez - e

\footnotetext{
${ }^{57}$ Alguns estudos recentes trataram disso em detalhe. Há, para citar alguns, o livro de Annick Ettlin intitulado "Le double discours de Mallarmé" (2017), o artigo de Marchal, "Le double état de la parole: fortune et infortune" (2019) e um texto de minha autoria, intitulado "A relação e o relacional para ler a obra de Mallarmé hoje: uma abordagem (re)tradutória" (2021).

${ }^{58}$ Tradução de todos os textos de "Anedotas ou poemas" (Divagações).

59 Texto de "Anedotas ou poemas" (Divagações).

${ }^{60} \mathrm{O}$ primeiro pertencente a "Quanto ao Livro" e o segundo consistindo numa sessão independente de Divagações.

${ }^{61}$ À exceção de "Conflito", tradução de todos os textos de "Anedotas ou poemas" (Divagaçães).
} 
essa é minha aposta pessoal - estejamos lendo mais e melhor Mallarmé; dando predileção a seus textos, sem no entanto descartar o que já foi dito sobre eles. Significa igualmente que a retradução, que o espaço da retradução e que a reflexão a respeito da tradução de forma mais global, cumprem um papel singular nessa renovação em nosso olhar para o poeta, ajudando-nos a ressignificar a complexidade de obras já muito comentadas e muitas vezes circunscritas a um espectro de si mesmas, o qual cremos definitivo ou incontornável. A reflexão de Berman sobre a retradução nos ajuda a ser menos - ou a ser diferentemente - assombrados por esses espectros, a compreendê-los antes em sua historicidade em relação com a historicidade própria à obra poética e, diante dessa compreensão, permite-nos a elaboração de contribuições próprias, de nosso tempo, em diversas línguas e geografias, para a permanência das obras, principalmente daquelas que, como a de Mallarmé, estão na gênese do que chamamos de contemporâneo.

\section{Referências bibliográficas}

AUSTIN, Lloyd James. How ambiguous is Mallarmé? Reflections on the captive Swan. In: BURNS, C. A. (ed.) Literature and Society: Studies in Nineteenth and Twentieth Century French Literature. Birmingham: John Goodman \& Sons, 1980. p. 102-114.

AUSTIN, Lloyd James. Presence and poetry of Stéphane Mallarmé: international reputation and intellectual impact. In: Poetic principles and practice: occasional papers on Baudelaire, Mallarmé and Valéry. Cambridge: Cambridge University Press, 1987. p. 19-47.

AUSTIN, Lloyd James. Essais sur Mallarmé. Manchester and New York: Manchester University Press, 1995.

BERMAN, Antoine. Critique, commentaire et traduction (Quelque réflexions à partir de Benjamin et de Blanchot). Po\&sie (Paris), n. 37, p. 88-106, 1986.

BERMAN, Antoine. Da translação à tradução. Trad. Marie-Hélène Torres e Marlova Aseff. Scientia Traductionis, Florianópolis, n. 9, p. 71-100, 2011. [1988a] 
BERMAN, Antoine. L'épreuve de l'étranger: Culture et traduction dans l'Allemagne romantique: Herder, Goethe, Schlegel, Novalis, Humboldt, Schleiermacher, Hölderlin. Paris: Tel/Gallimard, 1984.

BERMAN, Antoine. La retraduction comme espace de la traduction. Retraduire - Revue Palimpsestes (Paris), n. 4, p. 01-07, out. 1990.

BERMAN, Antoine. A tradução e a letra, ou, o Albergue do longínquo. Trad. Marie-Hélène Catherine Torres, Mauri Furlan e Andreia Guerini. Rio de Janeiro: 7Letras/PGET, 2007. [1985]

BERMAN, Antoine. Tradition - translation - traduction. Po\&sie (Paris), $\mathrm{n}$. 47, p. $85-98,1988$ b.

CAMPOS, Haroldo de. A palavra vermelha de Hölderlin. In: A arte no horizonte do provável. São Paulo: Perspectiva, 1975.

CARDOZO, Maurício. O significado da diferença: a dimensão crítica da noção de projeto de tradução literária. Tradução e comunicação: Revista Brasileira de Tradutores, São Paulo, n. 18, p. 101-107, 2009.

FALEIROS, Álvaro. A tradução do poema no Brasil: algumas tendências atuais. In: CYNTRÃO, Sylvia Helena (org.). Poesia: o lugar do contemporâneo. Brasília: Universidade de Brasília, 2009.

FALEIROS, Álvaro. Os tempos de Mallarmé nas antologias brasileiras de poesia traduzida. Revista Letras, Curitiba, n. 95, p. 143-163, jan./jun. 2017.

FALEIROS, Álvaro. Salut: a modernidade de Mallarmé em tradução. Traduzires 2, Brasília, dez. 2012a.

FALEIROS, Álvaro. Três Mallarmés: traduções brasileiras. Aletria, Belo Horizonte, v. 22, p. 17-31, 2012 b.

FALEIROS, Álvaro; MATTOS, Thiago. Retradução de poetas franceses no Brasil: de Lamartine a Prévert. São Paulo: Rafael Copetti Editor, 2017.

FAUSTINO, Mario. Poesia não é brincadeira. In: BOAVENTURA, Maria Eugenia (org.) Artesanatos de poesia. São Paulo: Cia das Letras, 2004. p. 159183. [1957]

LARANJEIRA, Mário. Poética da tradução. São Paulo: Edusp/FAPESP, 2003. [1993] 
MALLARMÉ, Stéphane. Correspondance. Lettres sur la poésie. Ed. de Bertrand Marchal. Paris: Folio/Gallimard, 1995.

MALLARMÉ, Stéphane. Guvres Complètes. Ed. de Bertrand Marchal. v. 2. Paris: Gallimard, Bibliothèque de la Pléiade, 2003.

MICAELIA, Caroline P. Mallarmé de volta à França. Retradução e recepção em “The Impressionists and Édouard Manet". 2019. Dissertação (Mestrado) - Curso de Letras Estrangeiras e Tradução. Universidade de São Paulo, São Paulo. 2019.

PETRY, Simone. Antoine Berman, leitor do romantismo alemão. Scientia Traductionis, Santa Catarina, n. 11, p. 368-376, 2012.

PETRY, Simone. Retradução e o princípio da abundância. Tradução em Revista, Rio de Janeiro, n. 19, p. 167-180, 2015.

SIMON, Sherry. Antoine Berman ou l'absolu critique. TTR, Ontário, v. 4, n. 2, p. 19-29, 2001.

STROPARO, Sandra. Mallarmé no Brasil. Revista Letras (UFSM) online, v. 23, 2013, p. 175-202.

\section{Resumo}

Este trabalho tem por objetivo estudar a obra e a recepção de Stéphane Mallarmé (1842-1898) por meio dos trabalhos de Antoine Berman (19421991), principalmente quanto à retradução. De fato, há interessantes correlações entre o Berman de "La retraduction comme espace de la traduction" (1990) e a vertente europeia dos estudos mallarmeanos no final do século XX. Elas se dão, majoritariamente, pela valorização de ideias como a metacrítica e a historicidade, advindas de um pensamento sobre o romantismo alemão. Mas divergem quanto à tradução. Na realidade, a tradução e as abordagens tradutórias estão notavelmente ausentes do debate europeu sobre Mallarmé. A tradução, contudo, é um importante e arrojado modo de contribuir com a pesquisa em literatura, como parece atestar o contexto das retraduções de Mallarmé no Brasil das décadas de 1980 e 1990. Por meio de um estudo da poesia e da recepção de Mallarmé à luz do pensamento de Berman, explora-se aqui um exemplo do quão criticamente 
longe as abordagens tradutórias podem ir - às vezes até mais do que os próprios estudos literários - no esforço de perpetuar obras consagradas.

Palavras-chave: Stéphane Mallarmé; Antoine Berman; Retradução; Recepção; Crítica.

\begin{abstract}
In this paper, I study Stéphane Mallarmé's oeuvre and reception through the lens of Antoine Berman's theory; especially his idea of retranslation. There are indeed interesting connections between Berman's "La retraduction comme espace de la traduction" and late-20th Century European Mallarmé Studies. They both base their conceptions of Metacritic and Historicity on German romantic ideas, though rather diverging when it comes to translation. In fact, translation and translative approaches are remarkably absent from European Mallarmé Studies. Yet, translation is an important and bold means for contributing with literary research, as the context of Mallarmé retranslation in 1980s and 1990s Brazil seems to endorse. By studying Mallarmé's poetry and reception under Berman's light, I explore here an example of just how critically far translative approaches can go sometimes even farther than Literary Studies themselves - in the effort of perpetuating consecrated oeuvres.
\end{abstract}

Keywords: Stéphane Mallarmé; Antoine Berman; Re-Translation; Reception; Critique. 